\title{
FOOD CONSUMPTION AND NUTRITIONAL STATUS OF CHILDREN PARTICIPATING AT POSYANDU PROGRAM IN CIANJ UR REGENCY
}

\author{
(Konsumsi Pangan dan Status Gizi Anak Peserta Posyandu di Kabupaten Cianjur) \\ Hadi Riyadi ${ }^{1}$ and Faisal Anwar ${ }^{1}$
}

\begin{abstract}
ABST RAK
Tujuan dari penelitian ini adalah untuk mengidentifikasi konsumsi pangan anak balita serta menganalisis status gizi balita. Penelitian ini menggunakan cross-sectional desain dengan sampel rumah tangga yang memiliki anak balita. Sampel berjumlah 300 balita. Pemilihan sampel dilakukan secara acak berlapis (stratified random sampling). Penelitian ini dilakukan di dua kecamatan Kabupaten Cianjur pada tahun 2006-2007. Data yang dikumpulkan meliputi konsumsi dan frekuensi konsumsi pangan balita serta data antropometri balita yang digunakan untuk menentukan status gizi balita. Data hasil wawancara dan pengukuran dientri menggunakan software excel. Data dianalisis dengan SAS (Statistical Analysis System). Hasil penelitian menunjukkan bahwa konsumsi energi balita secara ratarata hanya memenuhi $80 \%$ angka kecukupan gizi yang dianjurkan (RDA). Konsumsi protein sudah memenuhi angka kecukupan protein yang dianjurkan. Prevalensi underweight, stunted dan wasted pada balita berturut-turut yaitu 30.0\% 43.7\% dan $12.3 \%$
\end{abstract}

Keywords : konsumsi, frekuensi konsumsi pangan, dan status gizi

\section{INTRODUCTION}

\section{Background}

The economic crisis striking in Indonesia in 1997 is considered to have a big impact on the decreased quality of public health particularly for the poor people. From the results of evaluation on Posyandu (Health and Nutrition Integrated Service Center) carried out in November and December 1998, it has been found that the economic crisis has led to an increased number of undernourished children under five year old. The results of National Census show that the prevalence of undernourishment for under five year old children in 1989 was $37.5 \%$ (7 986279 children under five year old) and in 2003 27.3\% (5 117409 children). The absolute value of undernourist indicated that so far the nutritional programs have not yet been adequately effective and efficient in reducing nutritional problems.

The nutritional status of a community is influenced by a lot of interrelated and complex factors. At the level of households, the nutritional status is affected by the household ability to provide adequate food in both quantity and quality, mother's pattern of upbringing children, knowledge of nutrition, and other socio-cultural factors. This indicates a close relation between food security along with its nutritional status and public health (Azwar, 2004).

An improved status of community nutrition has a quite significant effect on the improvement of human resource quality. A nutritional status is a determinant factor of living quality and work performance. A high infant mortality rate, children under five years old and pregnant women, and a decreased work performance as well as retarded mental development and intelligence are as a result directly or indirectly of malnutrition.

Riyadi (1995) defines nutritional status as a body health condition of a person or a group of people resulting from the consumption, absorption, and utilization of nutrients in food. The physical size of a person is closely related to the nutritional status; for this reason anthropometry is accepted as a good indicator and reliable to determine a nutritional status.

\section{Goals and Objectives}

The objectives of this research were :

1. To identify food consumption of children under five years old.

2. To analyze nutritional status of children under five years old.

\footnotetext{
${ }^{1}$ Lecturer on Department of Community Nutrition, Faculty of Human Ecology, Bogor Agricultural University (IPB).
} 


\section{METHODS}

\section{Design}

This research used a cross-sectional design with samples of households who have children under five. The study was conducted in the District of Cianjur, the Province of West Java and two subdistricts were selected. The research has been conducted in 2006-2007. This article is part of study of Nutrition Program Implementation: Its Utilization by Households, Coverage, Effectiveness, and Impact on Nutritional Status in Poor Areas.

\section{Sampling}

The populations in this research are children under five years old. The populations were selected in two subdistricts (Karang Tengah and Ciranjang) of Cianjur District, West Java. Sampling was done using stratified random sampling with proportional allocation where high and low frequency visit stand as stratum. Sample size was also proportional with respect to Posyandu size. Sample sizes of children under five years old are 186 in Karang Tengah, while 114 in Ciranjang. Total sample sizes are 300 under-five-years children.

Cianjur District was selected since there were variations in nutrition program implemented and variations in achieving the program objectives (Personal Communication with Staff of Health Services, Cianjur, February 10, 2006). The two subdistricts were chosen to increase heterogeneity of samples, so that the performance of nutrition program was truly represented by the selected samples.

\section{Data collection}

The data collected consists of :

1. Data on food consumption and food frequency.

2. Nutritional status data (age, sex, weight and height).

The data were collected through questionnaires. The data on food consumption was collected with the food frequency and $1 \times 24$ hour food recall. Data of nutritional status was obtained by measuring height and weighing the weight of Children.

\section{Data Analysis and Management}

Data processing involves editing questionnaires, coding, and arrangement of file structure, data entry, editing files, raising variables, combining and separating files. Data processing and analysis used Excel and Statistical Analysis System.

The estimations of means and standard deviation made for all quantitative variables. The estimation results were presented in the forms of tables and diagrams.

\section{RESULTS}

\section{Consumption and Nutrition Adequacy of Children}

Energy Consumption. Food has been the primary need for human to live healthily (Harper, Deaton \& Driskel, 1986). The more varied the food stuffs consumed, the more varied the nutrients would be obtained, resulting in the improvement of nutritional quality. Consumption and energy/nutrients adequacy are presented at Table 1 and Table 2. The average energy consumption is 1094 $\mathrm{kcal} /$ day as seen at Table 1.

Table 1. Statistics of Nutrients Consumption of Children under Five Years Old

\begin{tabular}{|c|c|c|c|}
\hline \multirow[b]{2}{*}{ Nutrients } & \multicolumn{3}{|c|}{$\begin{array}{l}\text { Frequency of Posyandu } \\
\text { Visiting }\end{array}$} \\
\hline & $\begin{array}{c}\text { Low } \\
(n=180) \\
(\bar{X} \pm s d)\end{array}$ & $\begin{array}{c}\text { High } \\
(\mathbf{n}=120) \\
(\bar{X} \pm s d)\end{array}$ & $\begin{array}{c}\text { Total } \\
(\mathrm{n}=300) \\
(\bar{X} \pm \mathrm{sd})\end{array}$ \\
\hline Energy (kkal) & $1142 \pm 564$ & $1021 \pm 576$ & $1094 \pm 571$ \\
\hline Protei & $33.7 \pm 18.6$ & $30.7 \pm 18.6$ & $32.5 \pm 18.6$ \\
\hline Calcium $(1$ & $523 \pm 413$ & $477 \pm 414$ & $504 \pm 413$ \\
\hline Phosfor (n & $551 \pm 316$ & $523 \pm 335$ & $540 \pm 324$ \\
\hline Iron (mg) & $14.0 \pm 17.4$ & $11.0 \pm 12.6$ & $12.8 \pm 15.7$ \\
\hline Vitamin A & $689 \pm 920$ & $612 \pm 643$ & $378 \pm 48$ \\
\hline Vitami & $37.6 \pm 33.6$ & $33.1 \pm 27.8$ & $35.8 \pm 31.5$ \\
\hline Vitamin B1 (mg) & $0.34 \pm 0.19$ & $0.32 \pm 0.18$ & $0.33 \pm 0.18$ \\
\hline
\end{tabular}

On the average, this energy consumption only fulfills $80 \%$ of the nutrition adequacy recommended by RDA. It can be seen from the two participation groups (Table 1) that the energy consumption of the children of low participation group (1142 $\mathrm{kcal} / \mathrm{day})$ is a little higher than that of high participation group (1021 kcal/day).

According to Hardinsyah and Martianto (1998), nutrition deficiency especially in energy and protein at the initial stage only causes the feeling of hunger; however, in a certain period, this will cause the reduction (loss) of body weight. With this low level of energy consumption, children will only obtain 
two-third of the recommended energy adequacy level (RDA) (Table 2).

Tabel 2. Statistics of Nutritional Adequacy of Children Under Five Years Old

\begin{tabular}{|l|r|r|r|}
\hline \multirow{2}{*}{ Nutrients } & \multicolumn{3}{|c|}{ Frequency of Posyandu Visiting } \\
\cline { 2 - 4 } & $\begin{array}{c}\text { Low } \\
(\mathbf{n = 1 8 0 )} \\
(\bar{X} \pm \mathbf{s d})\end{array}$ & $\begin{array}{c}\text { High } \\
(\mathbf{n}=\mathbf{1 2 0}) \\
(\bar{X} \pm \mathbf{s d})\end{array}$ & $\begin{array}{c}\text { Total } \\
(\mathbf{n}=\mathbf{3 0 0 )} \\
(\bar{X} \pm \mathbf{s d})\end{array}$ \\
\hline Energy (\%) & $82.9 \pm 40.3$ & $76.9 \pm 44.9$ & $80.5 \pm 44.2$ \\
\hline Protein (\%) & $132.7 \pm 70.9$ & $125.6 \pm 79.9$ & $129.9 \pm 74.6$ \\
\hline Calcium (\%) & $105.1 \pm 82.9$ & $96.7 \pm 86.2$ & $101.8 \pm 84.2$ \\
\hline Phosfor (\%) & $198.2 \pm 109.0$ & $192.7 \pm 122.1$ & $196.0 \pm 114.2$ \\
\hline Iron (\%) & $170.5 \pm 209.3$ & $137.8 \pm 158.7$ & $157.6 \pm 191.2$ \\
\hline Vitamin A (\%) & $181.9 \pm 235.3$ & $164.6 \pm 167.2$ & $175.0 \pm 210.8$ \\
\hline Vitamin C (\%) & $90.7 \pm 80.5$ & $81.0 \pm 68.7$ & $86.9 \pm 76.1$ \\
\hline Vitamin B1 (\%) & $59.9 \pm 32.3$ & $58.2 \pm 34.9$ & $59.2 \pm 33.3$ \\
\hline
\end{tabular}

Protein Consumption. Table 1 shows that the average protein consumption among children is $32.5 \mathrm{~g} /$ day. As a whole, the protein consumption is much higher than the recommended protein adequacy level (129. 0\%). On the other hand, if seen from each participation group (Table 1), it can be said that the average protein consumption of low participation group is $33.7 \mathrm{mg}$ which has no significant difference from that of high participation group $(30.7 \mathrm{mg})$. The protein adequacy level of the children is greater than the recommended level (Table 2). This protein usually derives from salty fish.

Calcium Consumption. The calcium consumption by children is generally high, with the average consumption of $504 \mathrm{mg}$ per day. The average protein consumption in low participation group is $523 \mathrm{mg}$ higher than that of the children in high participation group (477 $\mathrm{mg}$ ) (Table 1). The consumption level indicates that their need has been satisfied (Table 2). The calcium source greatly consumed by them is from anchovies.

Phosphor Consumption. The average consumption of phosphor is $540 \mathrm{mg} /$ day (Table 1 ) in which the level has doubled the recommended phosphor adequacy level (Table 2). The consumption of both groups is not significantly different.

Iron Consumption. The tables show that the average iron consumption is approximately $12.8 \mathrm{mg} /$ day. Iron consumption for the low group is rather higher $(14.0 \mathrm{mg} /$ day $)$ than that of the high group $(11.0 \mathrm{mg} /$ day $)$. The adequacy level of iron has reached $150 \%$. The iron consumption level in the low group is 170\% whereas that of high group reaches 138\% (Table 2).

Vitamin A Consumption. The average consumption of vitamin $A$ is 658 ugRE or reaches $175 \%$ of the recommended level. The consumption of vitamin A for the low group is 689 ugRE and has reached $182 \%$ of the recommended level whereas that of the high group reaches 165 ugRE and has reached $165 \%$ of the recommended level.

Vitamin C Consumption. The average consumption of vitamin $\mathrm{C}$ is $35.8 \mathrm{mg}$ or only reaches $87 \%$ of the recommendation. There is no big difference in vitamin $\mathrm{C}$ consumption between low and high groups. This indicates that food quality is varied among the children, which may not be related to their participation at posyandu.

Vitamin B1 Consumption. The average consumption of vitamin B1 is $0.33 \mathrm{mg}$ or meets $59 \%$ of the recommended adequacy. The vitamin B1 consumption has no difference in both participation groups.

\section{Food Frequency of Children}

The Frequency of Staple Foods. Cereal food types (rice, corn, and wheat) contain high carbohydrates and sufficient protein content which will be utilized as energy sources (Winarno, 1995). The food frequency among children is presented to see their eating habits/patterns in the research area. From Table 3 , the cereals consumed by the children include rice, corn, cassava and sweet potato, and more than $80 \%$ of them consume these foods.

No difference in the frequency of cereal food consumption between the two groups. These cereal foods are mostly purchased, and they are rarely planted or given by other people. Rice is commonly purchased - this is claimed by $90 \%$ of the respondents.

Frequency of Animal Protein Consumption. Animal products contain the highest biological value of animal protein. Based on its characteristics, animal protein contains relatively high mineral and protein contents including various vitamins especially the unique vitamin B12 (Winarno, 1995). Types of animal protein sources include meat products, fish and eggs which are consumed everyday by more than $95 \%$ of the children. The foods consumed 4 times per week include salty fish and eggs (Table 4). Chicken meat and preserved 
fish (pindang) are generally consumed once a week.

There is no difference in the frequency of animal protein consumption between the two groups. Most of these products are purchased. Only a little portion of the products are obtained from the animals raised by the respondents. There are $10 \%$ respondents stating that fresh water fish products are obtained from their own ponds or they are given by their neighbors.

Frequency of Legumes Consumption. Soybeans are the sources of vegetable proteins. They are not commonly consumed everyday by the children (Table 5 ). Tofu and fermented soybean (tempeh) are consumed by more than $98 \%$ of the children with the fre- quency of 3 times per week. This might happen because these products are easily obtained and cheap. The research conducted by the Research Development Center of Nutrition in Bogor proves that the consumption of tempeh as one of the supplementary major food may increase body weight and improve the nutritional status of the children (Winarno, 1995). Other types of nuts are rarely consumed.

There is no difference in the frequency of soybean consumption between the two groups. Food of vegetable protein sources are almost 100.0 \% bought by respondents. Only few respondents those stated they obtained it from others people or self-cultivated.

Table 3. Statistics of Staple Food Consumption Frequency of Children under Five Years Old

\begin{tabular}{|c|c|c|c|c|c|c|}
\hline \multirow[t]{2}{*}{ Kinds of Staple Food } & \multirow{2}{*}{$\begin{array}{l}\text { Participation } \\
\text { at Posyandu }\end{array}$} & \multicolumn{2}{|c|}{$\begin{array}{l}\text { Children under } \\
\text { Five Years Old }\end{array}$} & \multicolumn{3}{|c|}{$\begin{array}{l}\text { Frequency of Consumption } \\
\text { (times per) }\end{array}$} \\
\hline & & $\mathbf{n}$ & $\%$ & Month & Week & Day \\
\hline \multirow{2}{*}{ Rice (Oryza sativa) } & Low & 180 & 100.0 & 76.8 & 17.7 & 2.5 \\
\hline & High & 120 & 100.0 & 74.3 & 17.2 & 2.5 \\
\hline \multirow{2}{*}{ Corn (Zea mays) } & Low & 152 & 83.9 & 2.1 & 0.5 & 0.1 \\
\hline & High & 99 & 83.2 & 2.5 & 0.6 & 0.1 \\
\hline \multirow{2}{*}{ Cassava (Manihot utilissima) } & Low & 150 & 82.8 & 1.2 & 0.3 & 0.04 \\
\hline & High & 100 & 84.0 & 1.4 & 0.3 & 0.1 \\
\hline \multirow{2}{*}{ Sweet potato (Ipomoea batatas) } & Low & 145 & 80.1 & 1.5 & 0.3 & 0.1 \\
\hline & High & 95 & 79.8 & 1.8 & 0.4 & 0.1 \\
\hline \multirow{2}{*}{ Taro (Colocasia esculenta) } & Low & 72 & 39.8 & 0.3 & 0.1 & 0.01 \\
\hline & High & 39 & 32.8 & 0.3 & 0.1 & 0.01 \\
\hline \multirow{2}{*}{ Potato (Solanum tuberosum) } & Low & 14 & 7.7 & 0.2 & 0.1 & 0.01 \\
\hline & High & 20 & 16.8 & 1.1 & 0.3 & 0.04 \\
\hline
\end{tabular}

Table 4. Statistics of Animal Protein Consumption Frequency of Children under Five Years Old

\begin{tabular}{|c|c|c|c|c|c|c|}
\hline \multirow[t]{2}{*}{ Kinds of Animal Protein } & \multirow{2}{*}{$\begin{array}{l}\text { Participation at } \\
\text { Posyandu }\end{array}$} & \multicolumn{2}{|c|}{$\begin{array}{l}\text { Children under } \\
\text { Five Years Old }\end{array}$} & \multicolumn{3}{|c|}{$\begin{array}{c}\text { Frequency of Consumption } \\
\text { (times per) }\end{array}$} \\
\hline & & $\mathbf{n}$ & $\%$ & Month & Week & Day \\
\hline \multirow{2}{*}{ Salty fish } & Low & 177 & 97.8 & 18.5 & 4.3 & 0.6 \\
\hline & High & 118 & 99.2 & 18.6 & 4.3 & 0.6 \\
\hline \multirow{2}{*}{ Layer chicken's egg } & Low & 179 & 98.9 & 18.4 & 4.2 & 0.6 \\
\hline & High & 115 & 96.6 & 18.8 & 4.3 & 0.6 \\
\hline \multirow{2}{*}{ Preserved fish } & Low & 173 & 95.6 & 8.1 & 1.9 & 0.3 \\
\hline & High & 115 & 96.6 & 6.8 & 1.6 & 0.2 \\
\hline \multirow{2}{*}{ Chicken meat } & Low & 180 & 99.5 & 5.4 & 1.3 & 0.2 \\
\hline & High & 118 & 99.2 & 4.6 & 1.1 & 0.2 \\
\hline \multirow{2}{*}{ Fresh water fish } & Low & 157 & 86.7 & 3.7 & 0.8 & 0.1 \\
\hline & High & 99 & 83.2 & 3.1 & 0.7 & 0.1 \\
\hline \multirow{2}{*}{ Sea water fish } & Low & 75 & 41.4 & 1.4 & 0.3 & 0.04 \\
\hline & High & 41 & 34.5 & 0.8 & 0.2 & 0.03 \\
\hline \multirow{2}{*}{ Chicken nugget } & LoW & 58 & 32.0 & 1.3 & 0.3 & 0.04 \\
\hline & High & 26 & 21.9 & 0.8 & 0.2 & 0.03 \\
\hline \multirow{2}{*}{ Kampong chicken's egg } & Low & 52 & 28.7 & 1.0 & 0.2 & 0.03 \\
\hline & High & 40 & 33.6 & 1.2 & 0.3 & 0.04 \\
\hline \multirow{2}{*}{ Beef/goat meat } & Low & 169 & 93.4 & 0.9 & 0.2 & 0.03 \\
\hline & High & 113 & 95.0 & 0.7 & 0.2 & 0.02 \\
\hline
\end{tabular}


Table 5. Statistics of Legumes Consumption Frequency of Children under Five Years Old

\begin{tabular}{|c|c|c|c|c|c|c|}
\hline \multirow[t]{2}{*}{ Kinds of Nuts } & \multirow{2}{*}{$\begin{array}{l}\text { Participation } \\
\text { at Posyandu }\end{array}$} & \multicolumn{2}{|c|}{$\begin{array}{l}\text { Children under } \\
\text { Five Years Old }\end{array}$} & \multicolumn{3}{|c|}{$\begin{array}{l}\text { Frequency of Consumption } \\
\text { (times per) }\end{array}$} \\
\hline & & $\mathbf{n}$ & $\%$ & Month & Week & Day \\
\hline \multirow{2}{*}{ Tofu } & Low & 180 & 100.0 & 16.4 & 3.8 & 0.5 \\
\hline & High & 120 & 100.0 & 15.1 & 3.5 & 0.5 \\
\hline \multirow[b]{2}{*}{ Tempeh } & Low & 177 & 97.8 & 14.3 & 3.3 & 0.5 \\
\hline & High & 119 & 100.0 & 14.3 & 3.3 & 0.5 \\
\hline \multirow[b]{2}{*}{ Mung-bean (Phaseolus vulgaris) } & Low & 157 & 86.7 & 4.7 & 1.1 & 0.2 \\
\hline & High & 108 & 90.8 & 3.5 & 0.8 & 0.1 \\
\hline \multirow{2}{*}{$\begin{array}{l}\text { Oncom (Traditional Indonesian } \\
\text { Fermented Food) }\end{array}$} & Low & 154 & 85.1 & 3.8 & 0.9 & 0.1 \\
\hline & High & 98 & 82.4 & 3.6 & 0.8 & 0.1 \\
\hline \multirow{2}{*}{ Peanut (Arachis hypogaea) } & Low & 155 & 85.6 & 3.9 & 0.9 & 0.1 \\
\hline & High & 98 & 82.4 & 3.0 & 0.7 & 0.1 \\
\hline \multirow{2}{*}{ Cowpea (Vigna unguiculata L.) } & Low & 6 & 3.3 & 0.1 & 0.02 & 0.0 \\
\hline & High & 4 & 3.4 & 0.1 & 0.03 & 0.0 \\
\hline
\end{tabular}

Frequency of Leaf Vegetables. Vegetables are sources of vitamin and minerals, those very useful for children under five. Generally, green vegetable is rich of important nutrients and its present on meals will improve the nutritional quality entirely.

Children under five rarely consumed leaf vegetables (Table 6). Frequency of leaf vegetables consumption only 1 time per week for mostly respondents. Kinds of those consumed leaf vegetables once a week are spinach, sawi (Brassica rugosa), carrot, long-bean (Cajanus cajan), and cabbage. There is no difference in the frequency of leaf vegetables consumption between the two groups.

Such vegetables as spinach, kangkung (Ipomoea reptans), carrot, sawi, cabbage, long-bean and melinjo leaves are commonly purchased by the respondents. Cassava and papaya leaves can be obtained by purchasing them or taking them from the respondents' garden or they obtained the leaves from their neighbors.

Frequency of Fruit Vegetable. Like leaf vegetables, fruit vegetables are also rarely consumed by the children (Table 7). From these types of vegetables, tomato are the most frequently consumed by the children i.e. 6 times per week or almost everyday. Fruit vegetables those consumed once a week are cucumber and pumpkin. There is no difference in the frequency of the consumption between the two groups.

Frequency of Fruit. Fruits are also vitamin and mineral sources. The largest sources of vitamin $C$ derive from fruits especially the fresh ones. In general, these fruits are not consumed daily by the children (Table 8 ). Oranges and banana are often consumed by the children i.e. 3 times a week since they are

Table 6. Statistics of Leaf Vegetables Consumption Frequency of Children under Five Years Old

\begin{tabular}{|c|c|c|c|c|c|c|}
\hline \multirow[t]{2}{*}{ Kinds of Leaf Vegetables } & \multirow{2}{*}{$\begin{array}{l}\text { Participation } \\
\text { at Posyandu }\end{array}$} & \multicolumn{2}{|c|}{$\begin{array}{l}\text { Children under } \\
\text { Five Years Old }\end{array}$} & \multicolumn{3}{|c|}{$\begin{array}{l}\text { Frequency of Consumption } \\
\text { (times per) }\end{array}$} \\
\hline & & $\mathbf{n}$ & $\%$ & Month & Week & Day \\
\hline \multirow{2}{*}{ Spinach } & Low & 172 & 95.0 & 8.1 & 1.9 & 0.3 \\
\hline & High & 115 & 96.6 & 8.7 & 2.0 & 0.3 \\
\hline \multirow{2}{*}{ Kangkung (Ipomoea reptans) } & Low & 177 & 97.8 & 7.7 & 1.8 & 0.3 \\
\hline & High & 115 & 96.6 & 9.0 & 2.1 & 0.3 \\
\hline \multirow{2}{*}{ Carrot } & Low & 178 & 98.3 & 7.3 & 1.7 & 0.2 \\
\hline & High & 116 & 97.5 & 7.8 & 1.8 & 0.3 \\
\hline \multirow{2}{*}{ Cabbage } & Low & 168 & 92.8 & 6.5 & 1.5 & 0.2 \\
\hline & High & 112 & 94.1 & 6.5 & 1.5 & 0.2 \\
\hline \multirow{2}{*}{ Sawi (Brassica rugosa) } & Low & 165 & 91.2 & 5.9 & 1.3 & 0.2 \\
\hline & High & 109 & 91.6 & 5.8 & 1.3 & 0.2 \\
\hline \multirow{2}{*}{ Long-bean (Caj anus caj an) } & Low & 174 & 96.1 & 4.7 & 1.1 & 0.2 \\
\hline & High & 115 & 96.6 & 4.6 & 1.1 & 0.2 \\
\hline \multirow{2}{*}{ Melinjo leaves (Gnetum gnemon) } & Low & 147 & 81.2 & 3.8 & 0.9 & 0.1 \\
\hline & High & 97 & 81.5 & 3.7 & 0.9 & 0.1 \\
\hline \multirow{2}{*}{ Cassava leaves } & Low & 154 & 85.1 & 3.1 & 0.7 & 0.1 \\
\hline & High & 100 & 84.0 & 3.7 & 0.9 & 0.1 \\
\hline \multirow{2}{*}{ Papaya leaves } & Low & 107 & 59.1 & 1.7 & 0.4 & 0.1 \\
\hline & High & 71 & 59.7 & 2.5 & 0.6 & 0.1 \\
\hline
\end{tabular}


Table 7. Statistics of Fruit Vegetables Consumption Frequency of Children under Five Years Old

\begin{tabular}{|c|c|c|c|c|c|c|}
\hline \multirow[t]{2}{*}{ Kinds of Fruit Vegetables } & \multirow{2}{*}{$\begin{array}{l}\text { Participation } \\
\text { at Posyandu }\end{array}$} & \multicolumn{2}{|c|}{$\begin{array}{l}\text { Children under } \\
\text { Five Years Old }\end{array}$} & \multicolumn{3}{|c|}{$\begin{array}{l}\text { Frequency of Consumption } \\
\text { (times per) }\end{array}$} \\
\hline & & $\mathbf{n}$ & $\%$ & Month & Week & Day \\
\hline \multirow{2}{*}{ Tomato } & Low & 180 & 100.0 & 26.8 & 6.2 & 0.9 \\
\hline & High & 118 & 99.2 & 28.1 & 6.5 & 0.9 \\
\hline \multirow{2}{*}{ Cucumber } & Low & 175 & 96.7 & 8.2 & 1.9 & 0.3 \\
\hline & High & 112 & 94.1 & 6.9 & 1.6 & 0.2 \\
\hline \multirow{2}{*}{$\begin{array}{l}\text { Pumpkin } \\
\text { (Legenaria leucantha) }\end{array}$} & Low & 176 & 97.2 & 5.4 & 1.3 & 0.2 \\
\hline & High & 114 & 95.8 & 4.8 & 1.1 & 0.2 \\
\hline \multirow{2}{*}{ Eggplant } & Low & 144 & 79.6 & 3.6 & 0.8 & 0.1 \\
\hline & High & 101 & 84.8 & 3.5 & 0.8 & 0.1 \\
\hline \multirow{2}{*}{ Baby jackfruit } & Low & 115 & 63.5 & 2.1 & 0.5 & 0.1 \\
\hline & High & 70 & 58.8 & 1.3 & 0.3 & 0.04 \\
\hline \multirow{2}{*}{ Baby papaya } & Low & 62 & 34.3 & 1.0 & 0.2 & 0.03 \\
\hline & High & 41 & 34.5 & 0.7 & 0.2 & 0.02 \\
\hline
\end{tabular}

Table 8. Statistics of Fruits Consumption Frequency of Children under Five Years Old

\begin{tabular}{|c|c|c|c|c|c|c|}
\hline \multirow[t]{2}{*}{ Kinds of Fruits } & \multirow{2}{*}{$\begin{array}{l}\text { Participation } \\
\text { at Posyandu }\end{array}$} & \multicolumn{2}{|c|}{$\begin{array}{l}\text { Children under } \\
\text { Five Years Old }\end{array}$} & \multicolumn{3}{|c|}{$\begin{array}{l}\text { Frequency of Consumption } \\
\text { (times per) }\end{array}$} \\
\hline & & $\mathbf{n}$ & $\%$ & Month & Week & Day \\
\hline \multirow{2}{*}{ Guava } & Low & 158 & 87.3 & 3.0 & 0.7 & 0.1 \\
\hline & High & 101 & 84.8 & 3.1 & 0.7 & 0.1 \\
\hline \multirow{2}{*}{ Papaya } & Low & 164 & 90.6 & 5.1 & 1.2 & 0.2 \\
\hline & High & 110 & 92.4 & 3.5 & 0.8 & 0.1 \\
\hline \multirow{2}{*}{ Mango } & Low & 168 & 92.8 & 4.3 & 1.0 & 0.1 \\
\hline & High & 104 & 87.4 & 3.6 & 0.8 & 0.1 \\
\hline \multirow{2}{*}{ Pineapple } & Low & 85 & 47.0 & 1.6 & 0.4 & 0.05 \\
\hline & High & 45 & 37.8 & 0.5 & 0.1 & 0.02 \\
\hline \multirow{2}{*}{ Banana } & Low & 176 & 97.2 & 11.8 & 2.7 & 0.4 \\
\hline & High & 116 & 97.5 & 12.3 & 2.8 & 0.4 \\
\hline \multirow{2}{*}{ Jackfruit } & Low & 140 & 77.4 & 1.1 & 0.3 & 0.04 \\
\hline & High & 78 & 65.6 & 1.0 & 0.2 & 0.03 \\
\hline \multirow{2}{*}{ Hairyfruit } & Low & 156 & 86.2 & 0.1 & 0.03 & 0.0 \\
\hline & High & 107 & 89.9 & 0.1 & 0.03 & 0.0 \\
\hline \multirow{2}{*}{ Orange } & Low & 179 & 98.9 & 13.8 & 3.2 & 0.5 \\
\hline & High & 117 & 98.3 & 13.3 & 3.1 & 0.4 \\
\hline \multirow{2}{*}{ Apple } & Low & 141 & 77.9 & 3.0 & 0.7 & 0.1 \\
\hline & High & 89 & 74.8 & 2.6 & 0.6 & 0.1 \\
\hline Melon & Low & 1 & 0.6 & 0.01 & 0.0 & 0.0 \\
\hline
\end{tabular}

easy to find and relatively cheap whereas papaya and mango are only consumed once a week. There is no difference in fruit consumption between the low and high participation groups.

Frequency of Snacks. Snacks containing carbohydrates are not consumed every day by the children (Table 9). Research by Widiyawati (2004) states that snacks frequently consumed by the children include chiki potato chips, candies, chocolate, and nuts. There is no difference in snacks consumption between the low and high participation groups. They are generally purchased from the small shops or traveling sellers.

Frequency of Miscellaneous Food. These miscellaneous foods such as sugar and monosodium glutamate (MSG) are almost consumed daily by the children (see Table 10).
This is because their mothers always put these foods into their meals to make them tastier. There is no difference in miscellaneous foods consumption between the low and high participation groups. Like the other foods, they are generally purchased by the children.

\section{Nutritional Status of Children}

\section{Anthropometric Characteristics of Children}

The average age of children in the research location is $2.7 \pm 1.0$ years, with lowest age of 1 year and the highest age of 5 years. The average age is relatively the same in both low and high participation groups. Similarly, there is no difference in the average age for different sexes in both participation groups at posyandu. 
Table 9. Statistics of Snacks Consumption Frequency of Children under Five Years Old

\begin{tabular}{|c|c|c|c|c|c|c|}
\hline \multirow[t]{2}{*}{ Kinds of Snacks } & \multirow{2}{*}{$\begin{array}{l}\text { Participation } \\
\text { at Posyandu }\end{array}$} & \multicolumn{2}{|c|}{$\begin{array}{l}\text { Children under } \\
\text { Five Years Old }\end{array}$} & \multicolumn{3}{|c|}{$\begin{array}{l}\text { Frequency of Consumption } \\
\text { (times per) }\end{array}$} \\
\hline & & $\mathbf{n}$ & $\%$ & Month & Week & Day \\
\hline \multirow{2}{*}{ Fried snacks } & Low & 179 & 98.9 & 20.5 & 4.7 & 0.7 \\
\hline & High & 116 & 97.5 & 19.0 & 4.4 & 0.6 \\
\hline \multirow{2}{*}{ Fried banana } & Low & 167 & 92.3 & 14.3 & 3.3 & 0.5 \\
\hline & High & 111 & 93.3 & 13.1 & 3.0 & 0.4 \\
\hline \multirow{2}{*}{ Meat ball } & Low & 174 & 96.1 & 8.9 & 2.1 & 0.3 \\
\hline & High & 114 & 95.8 & 8.4 & 1.9 & 0.3 \\
\hline \multirow{2}{*}{$\begin{array}{l}\text { Bakwan } \\
\text { (fried vegetables) }\end{array}$} & Low & 116 & 64.1 & 7.5 & 1.7 & 0.3 \\
\hline & High & 80 & 67.2 & 6.8 & 1.6 & 0.2 \\
\hline \multirow{2}{*}{ Siomay (kind of Chinese foods) } & Low & 110 & 60.8 & 3.8 & 0.9 & 0.1 \\
\hline & High & 68 & 57.1 & 3.0 & 0.7 & 0.1 \\
\hline \multirow{2}{*}{ Chicken noodle } & Low & 111 & 61.3 & 2.2 & 0.5 & 0.1 \\
\hline & High & 78 & 65.6 & 2.1 & 0.5 & 0.1 \\
\hline
\end{tabular}

Table 10. Statistics of Miscellaneous Food Consumption Frequency of Children under Five Years Old

\begin{tabular}{|c|c|c|c|c|c|c|}
\hline \multirow[t]{2}{*}{ Kinds of Miscellaneous Food } & \multirow{2}{*}{$\begin{array}{l}\text { Participation } \\
\text { at Posyandu }\end{array}$} & \multicolumn{2}{|c|}{$\begin{array}{l}\text { Children under } \\
\text { Five Years Old }\end{array}$} & \multicolumn{3}{|c|}{$\begin{array}{l}\text { Frequency of Consumption } \\
\text { (times per) }\end{array}$} \\
\hline & & $\mathbf{n}$ & $\%$ & Month & Week & Day \\
\hline \multirow{2}{*}{ Sugar } & Low & 180 & 100.0 & 27.6 & 6.4 & 0.9 \\
\hline & High & 117 & 98.3 & 26.4 & 6.1 & 0.9 \\
\hline \multirow{2}{*}{ Tea } & Low & 169 & 93.4 & 22.7 & 5.2 & 0.8 \\
\hline & High & 99 & 83.2 & 21.0 & 4.8 & 0.7 \\
\hline \multirow{2}{*}{ Coffee } & Low & 116 & 64.1 & 13.9 & 3.2 & 0.5 \\
\hline & High & 76 & 63.9 & 12.5 & 2.9 & 0.4 \\
\hline \multirow{2}{*}{ Sauce } & Low & 139 & 76.8 & 8.1 & 1.9 & 0.3 \\
\hline & High & 79 & 66.4 & 6.6 & 1.5 & 0.2 \\
\hline \multirow{2}{*}{ Kerupuk (fried crackers) } & Low & 178 & 98.3 & 18.7 & 4.3 & 0.6 \\
\hline & High & 116 & 97.5 & 18.1 & 4.2 & 0.6 \\
\hline \multirow{2}{*}{ Vetsin/MSG } & Low & 176 & 97.2 & 29.2 & 6.7 & 1.0 \\
\hline & High & 118 & 99.2 & 30.2 & 6.9 & 1.0 \\
\hline \multirow{2}{*}{ Soybean ketchup } & Low & 172 & 95.0 & 15.3 & 3.5 & 0.5 \\
\hline & High & 114 & 95.8 & 14.3 & 3.3 & 0.5 \\
\hline
\end{tabular}

On the whole, the average body weight of children is $11.3 \pm 2.7 \mathrm{~kg}$, with the lowest body weight of $6.3 \mathrm{~kg}$ and the highest of 26.1 $\mathrm{kg}$. The body weights in both participation groups are not much different, but the body weights of boys tend to be greater than those of girls in both participation groups.

The average body height of all children is $85.4 \pm 10.0 \mathrm{~cm}$, with the lowest body height of $59.5 \mathrm{~cm}$ and the highest of $112.1 \mathrm{~cm}$. The body heights of children are relatively not different between the two participation groups. Boys have greater body heights than girls in both participation groups. In the low group, the body heights of boys are about $2 \mathrm{~cm}$ higher than the girls. In the high group, the body heights of boys are about $4 \mathrm{~cm}$ higher than the girls.

\section{Weight for Age of Children (W/A)}

The nutritional status discussed in this report is based on the resulted measurement of body weights and heights, so the analysis uses the weight for age (W/A), height for age $(\mathrm{H} / \mathrm{A})$, and weight for height $(\mathrm{W} / \mathrm{H})$. The data processing uses WHO software, Antro 2005 and the new WHO anthropometric standard.

Based on the calculation of Z-score of W/A and the threshold point $<-2 S D$ for the underweight, the prevalence of underweight among children (less than five years old) is $30.0 \%$. The underweight prevalence is much higher at the research location than that in Indonesia (23.1\%) obtained by SUSENAS 2005 (National Survey of Social Economic). The underweight prevalence among children in the low participation group $(34.3 \%)$ is much higher than that among children in the high participation group (23.5\%).

There is no consistent pattern of underweight prevalence between sexes. In low participation group, the underweight prevalence is greater for boys, whereas in the high participation group it is greater for girls. The prevalence of severe underweight (Z-score $<-3$ SD) in the research location is $8.3 \%$, the same 
as the result obtained by SUSENAS in Indonesia.

The prevalence of overweight children is very low, i.e. $0.7 \%$. Overweight is more prevalent in the high participation group than in the low group. From Figure 1 it is clearly seen that the Z-score median of W/A for the children in the research site is much further to the left than the WHO standard of 2005. The median Z-score for the children in the research location is coming closer to the standard deviation of -1.5 or underweight.
The Z-score $(-1.52)$ for the children of the low participation group is worse that that $(-1.13)$ of the high participation group. Like the underweight prevalence, the Z-scores between different sexes do not have a consistent pattern. In the low participation group, the Zscore of W/A is higher for boys; whereas in the high participation group it is higher for girls. The gender-based analysis shows that the curve of Z-scores is not much different between boys and girls (see Figure 2). From Figure 5.3 it can be seen that in terms of age groups, the Z-score of W/A is the worst in its deviation for the age group of 24-47 months.

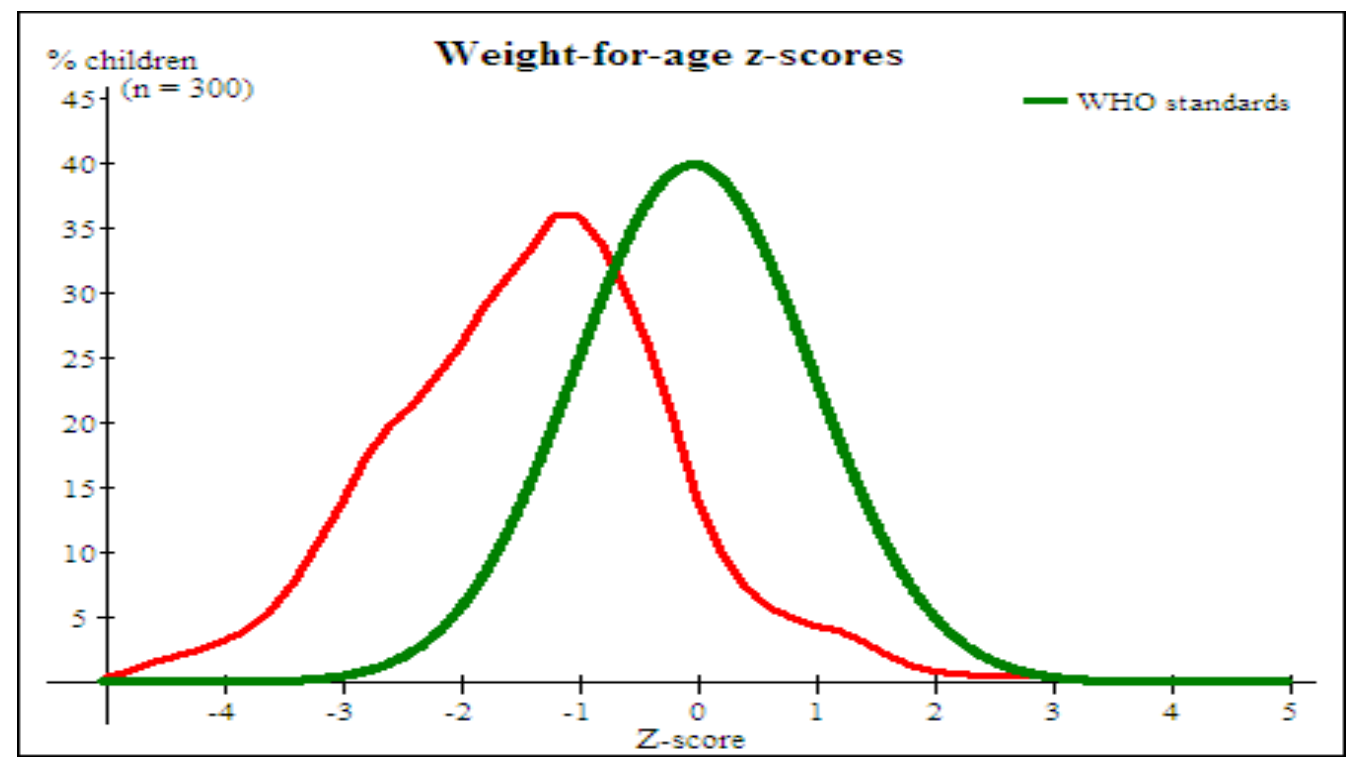

Figure 1. Distribution of Children based on the Z-score of W/A

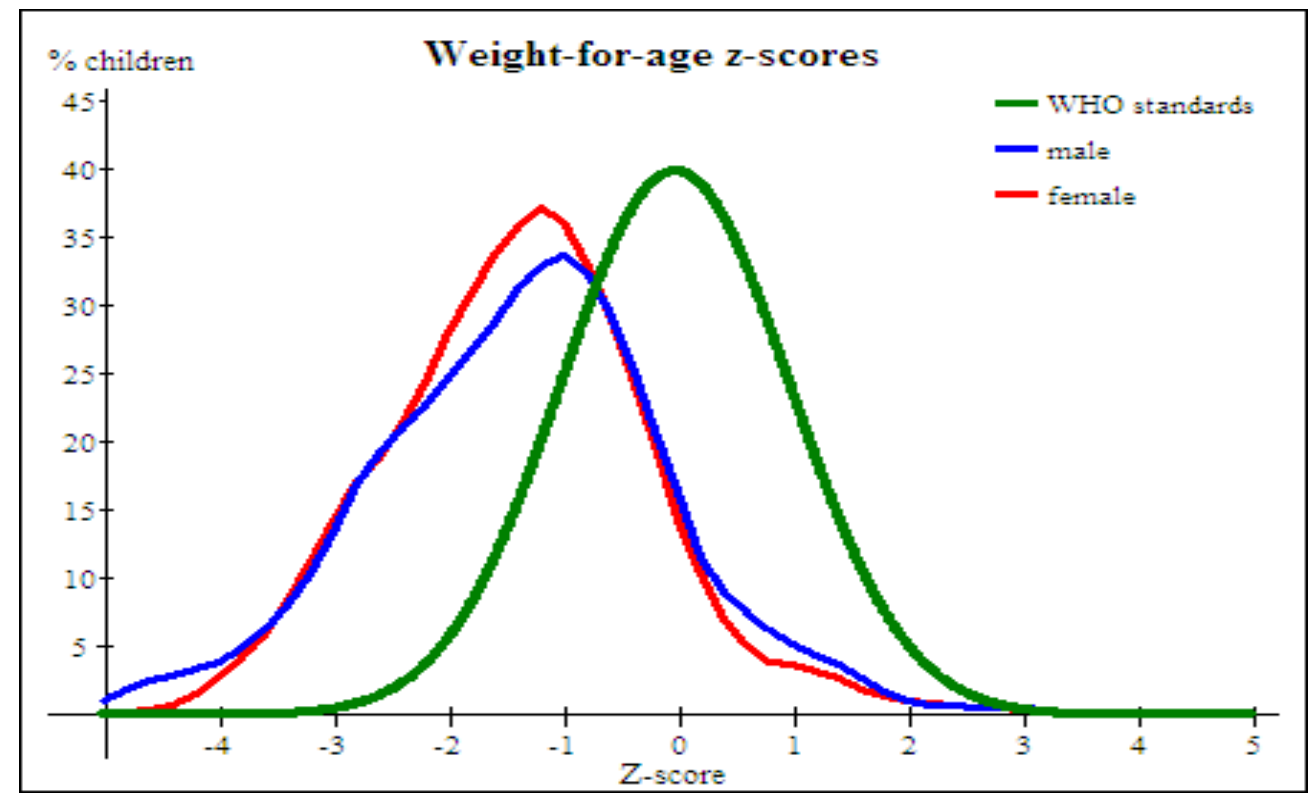

Figure 2. Distribution of Children based on the Z-score of W/A and Sex 


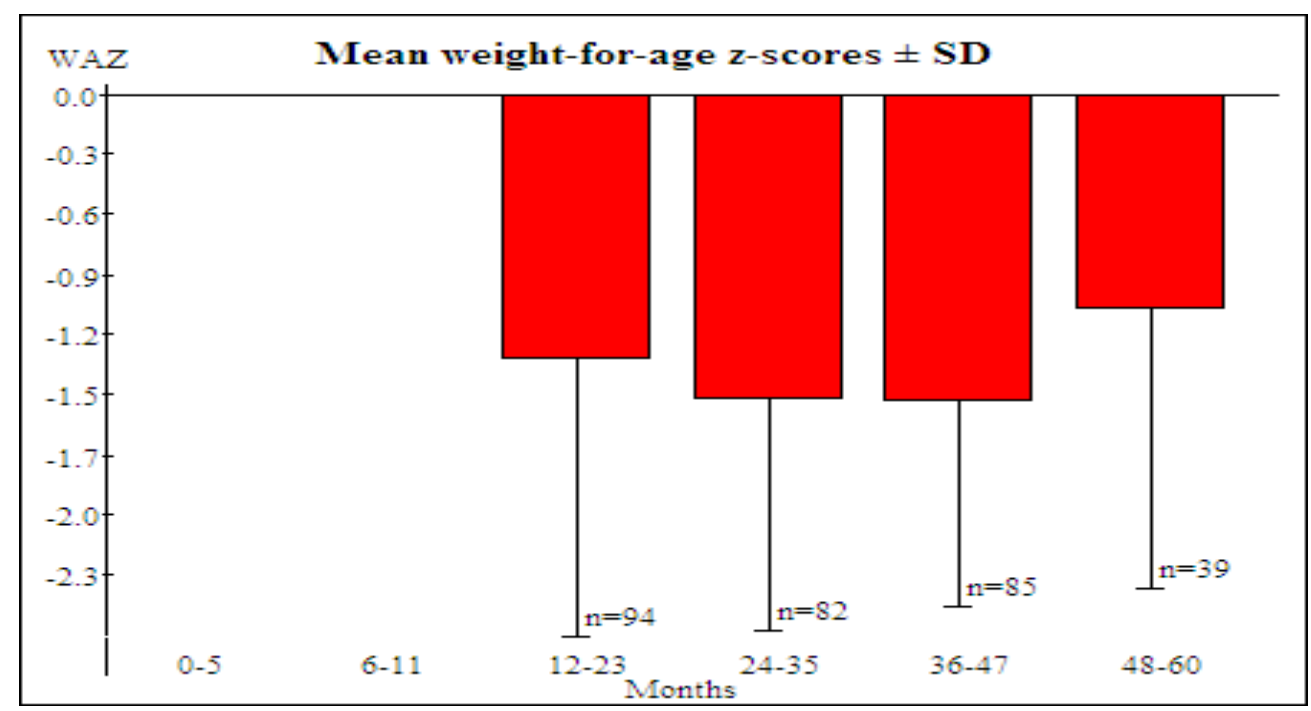

Figure 3. Z-score of W/A Value of Children based on Age Group

\section{Height for Age of Children (H/A)}

A body height at a certain time is the resulted cumulative growth since birth, therefore it can be used as a previous picture of nutritional status in the past. Body height is also the most sensitive index for detecting the socio-economic changes. The prevalence of stunted growth as a whole is $43.7 \%$. This prevalence is closer to the prevalence in Indonesia 5-6 years ago.

The comparison of the prevalence of stunted growth between participation groups shows that the prevalence is greater for children in the low participation $(46.4 \%)$ than in the high participation group (39.5\%). The stunted prevalence between different genders does not take a consistent pattern. In the low participation group, the stunted prevalence is higher among boys; whereas in the high participation group, it is greater among girls. The severe stunted prevalence (based the criteria of $<-3 \mathrm{SD}$ ) in this research is $20.3 \%$. Eating habit with a lack of animal protein and inadequate daily intake of energy can be the cause of severe stunted growth among children.

It can be seen from Figure 4 that the median Z-score of $\mathrm{H} / \mathrm{A}$ for the children in the research location is farther to the left than the standard of WHO, i.e. getting closer to -2 standard deviation or stunting.

The gender-based analysis shows that the curve for the Z-score of $\mathrm{H} / \mathrm{A}$ is slightly worse in the girls than in the boys (see Figure 4). The Z-score of H/A (-1.9) for children in the low participation group is worse than that of the high participation groups (-1.6).

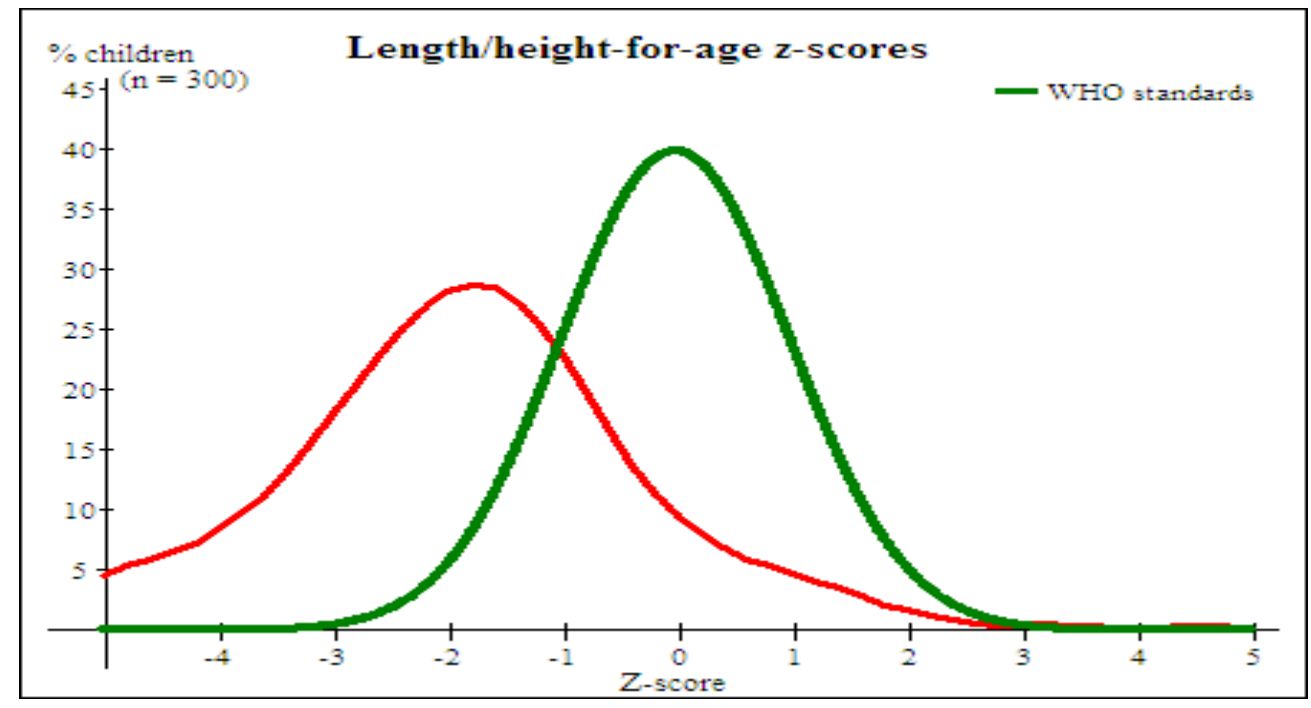

Figure 4. Distribution of Children based on the Z-score of H/A 


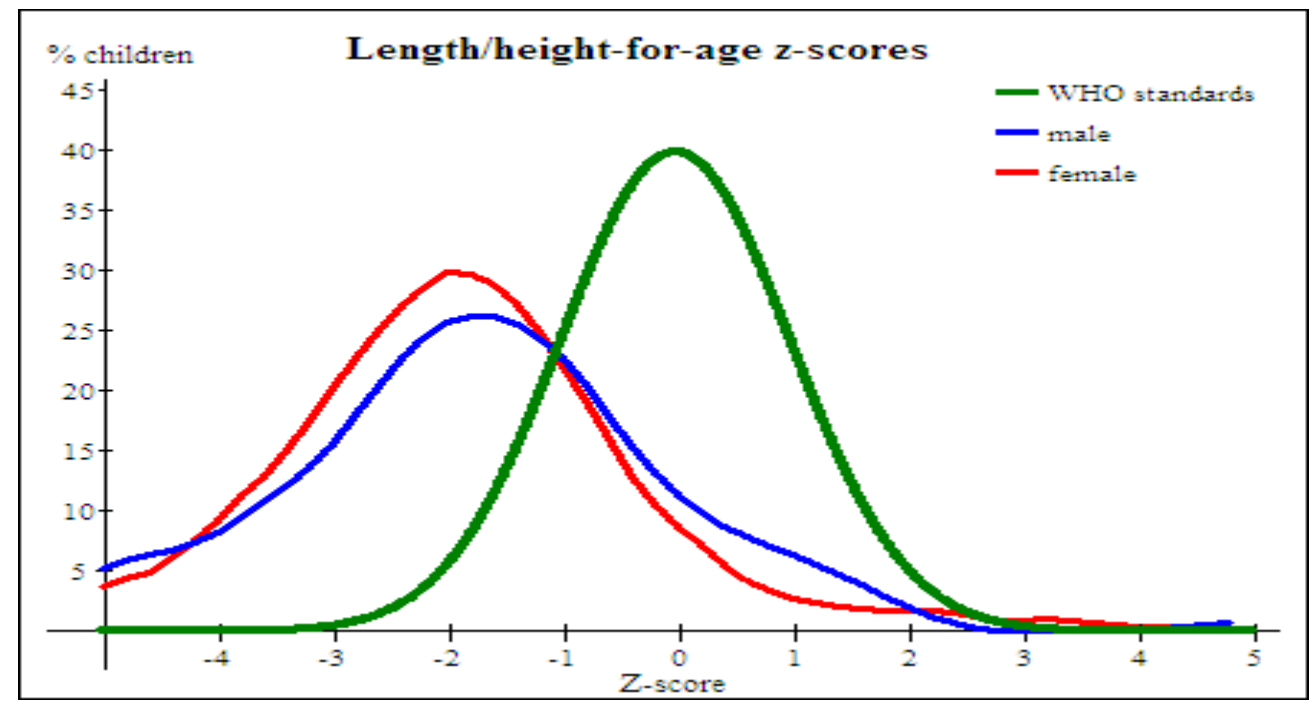

Figure 5. Distribution of Children according to the Z-score of H/A and Sex

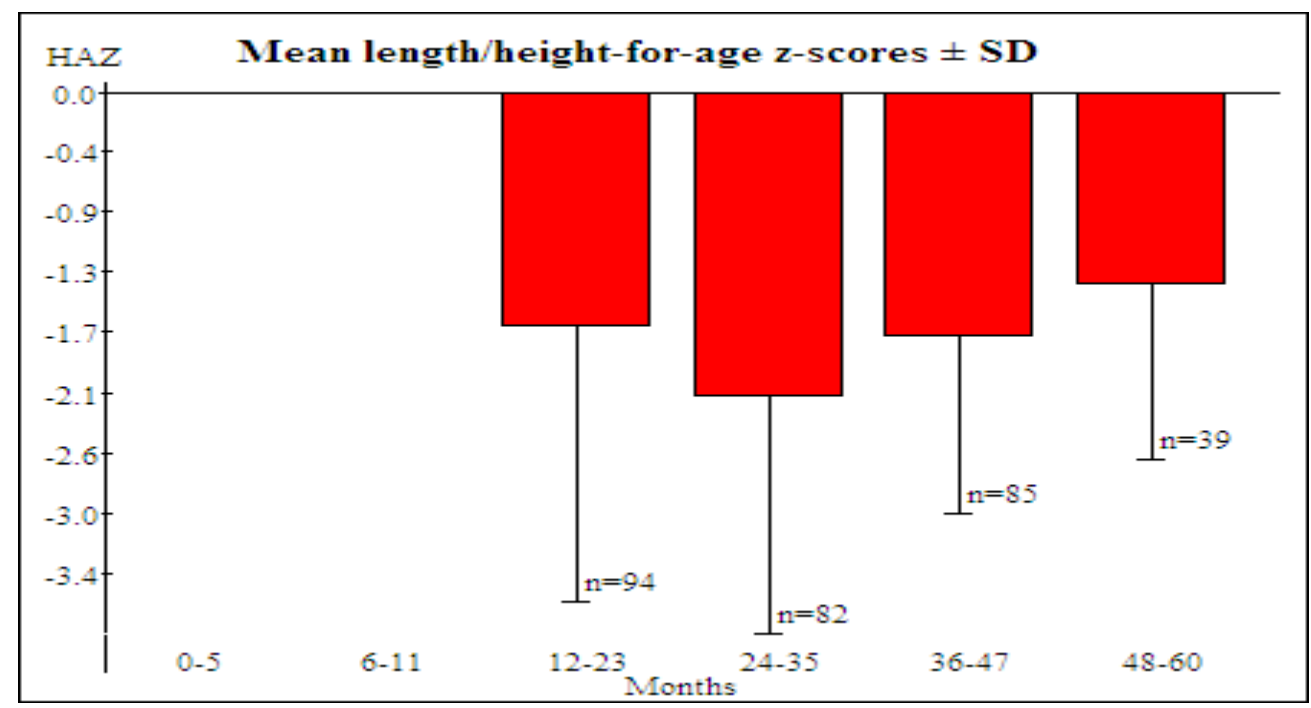

Figure 6. Z-score of H/A Value of Children based on Age Group

Like the underweight prevalence, Zscore of $\mathrm{H} / \mathrm{A}$ between different genders does not take a consistent pattern. In the low participation group, the boys have a higher Zscore of $\mathrm{H} / \mathrm{A}$, whereas in the high group the girls have a higher Z-score of $\mathrm{H} / \mathrm{A}$. Like in Figure 3 , in Figure 6 in terms of age groups it can be seen that the Z-score of $\mathrm{H} / \mathrm{A}$ is the worst in the age group of 24-35 months.

\section{Weight for Height of Children (W/H)}

Based on the calculation of Z-score of $\mathrm{W} / \mathrm{H}$ with the wasted criteria of $<-2 \mathrm{SD}$, the wasted prevalence is found to be $12.3 \%$. The prevalence of wasted children in the low participation growth $(14.9 \%)$ is much higher than that of the high participation group (8.4\%). The prevalence among the boys is higher than among the girls in both participation groups.
The prevalence of severe wasted ( $\mathrm{Z}$ score of <-3 SD) in this research is very low, i.e. $4.7 \%$. From Figure 7 it is clear that the median Z-score of $\mathrm{W} / \mathrm{H}$ for the children in the research location is rather away to the left compared to the WHO standard of 2005. The median Z-score of $\mathrm{W} / \mathrm{H}$ for the children in the area is approaching the standard deviation of 0.5 or wasting.

The gender-based analysis shows that the curve for the Z-score of $\mathrm{W} / \mathrm{H}$ among the boys is relatively the same as that among the girls (see Figure 8). The prevalence of wasted among the boys $(15.4 \%)$ is higher than that among the girls $(9.3 \%)$. Like in Figure 3 , in Figure 9 in terms of the age groups, it can be seen that the Z-score of $\mathrm{W} / \mathrm{H}$ is the worst in the age group of 36-47 months. 


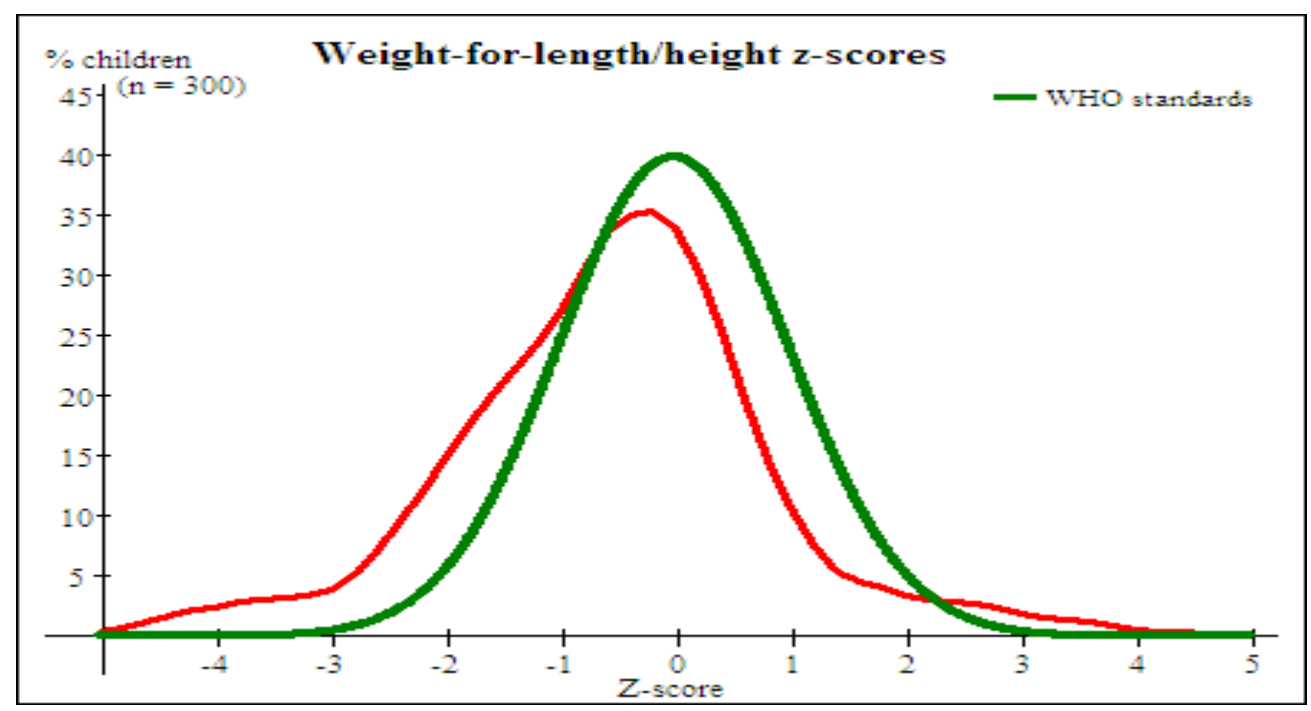

Figure 7. Distribution of Children according to the Z-score of W/H

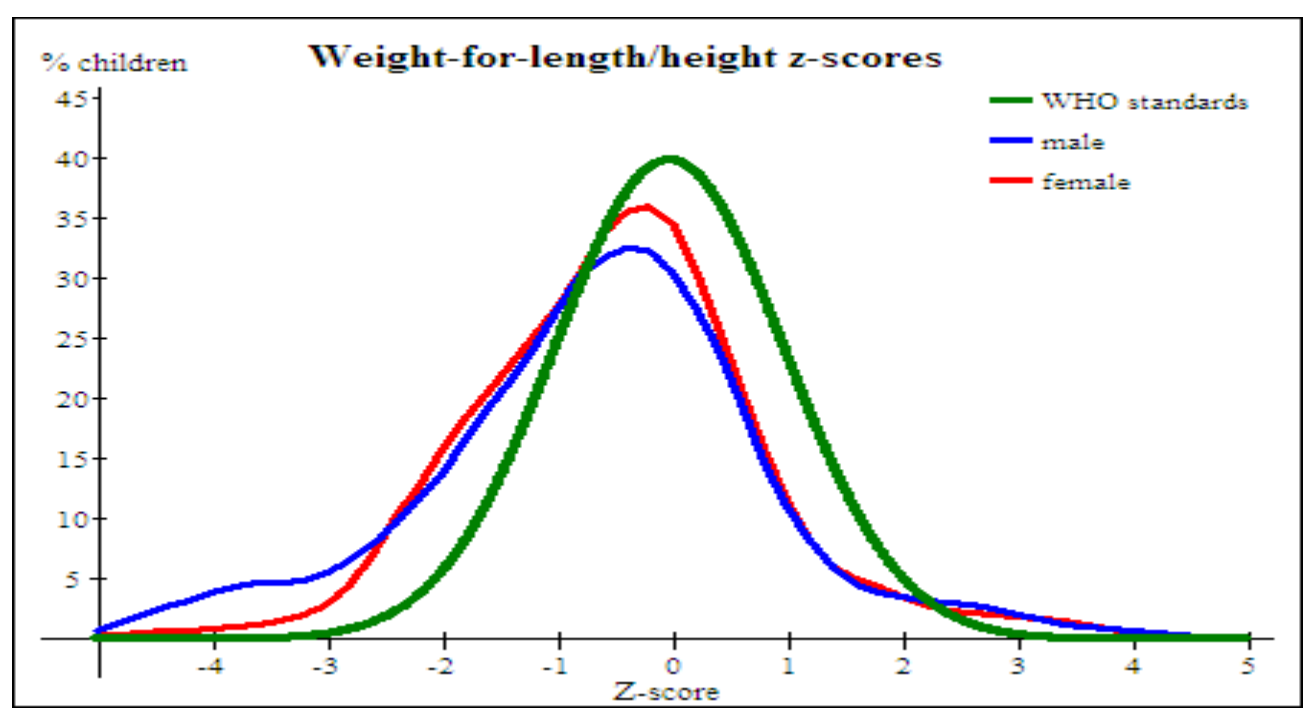

Figure 8. Distribution of Children based on the Z-score of W/H and Sex

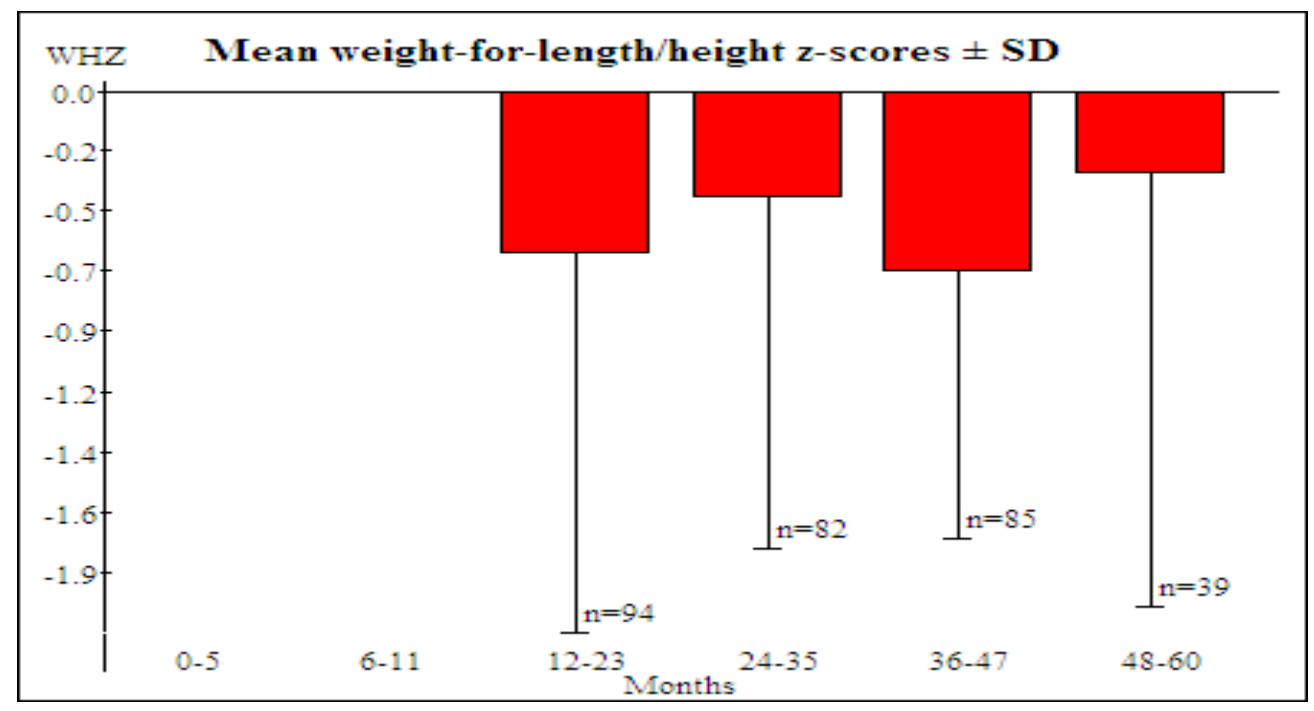

Figure 9. Z-score of W/H Value of Children based on Age Group 


\section{CONCLUSION AND RECOMENDATION}

\section{Conclusion}

1. The average consumption of energy for children under five years old is still below the recommended dietary allowance $(80 \%$ of RDA), whereas the protein consumption is already above the RDA.

2. The prevalence of underweight, stunted, and wasted among children are respectively $30.0 \%, 43.7 \%$, and $12.3 \%$

3. The activities at posyandus have a positive impact on the nutritional status of children under five year's olds. The more frequent the visit to posyandus, the better the three nutritional statuses would be

\section{Recommendation}

The consumption of children under five years old have impact on the nutritional status of them, so that mothers having children under five years old should improve the consumption of children. And then the nutritional knowledge of mothers is necessary to make effort in improving the consumption of children.

\section{ACKNOWLEDGEMENT}

The researchers would like to extend its gratitude to the Neys-van Hoogstraten Foundation (NHF), the Netherlands for funding this research project. Thank you and appreciation to Ali Khomsan, Dadang Sukandar, and Eddy S. Mudjajanto from Department of Community Nutrition, Faculty of Human Ecology, Bogor Agricultural University as other researchers who also involved in this project.

\section{BIBLIOGRAPHY}

Azwar A. 2004. Aspects of Health and Nutrition in Food Security. Paper of National Workshop on Food and Nutrition 2004. LIPI (Indonesian Institute of Science). Jakarta.

Hardinsyah \& D Martianto. 1988. Evaluation of Energy and Protein Adequacy Level and Nutritional Quality of Food Consumption. Wirasari, Jakarta.

Harper IJ, BJ Deaton, \& JA Driskel. 1986. Food, Nutrition, and Agriculture (Suhardjo, translator) $\left(2^{\text {nd }} E d.\right)$. UI Press, Jakarta.

Riyadi H. 1995. Evaluation and Measurement of Nutritional Status. Lecture Notes of Departement of Community Nutrition and Familly Resources, Faculty of Agriculture, IPB, Bogor.

Widiyawati R. 2004. Relation of Mother's Nutritional Knowledge and behaviour with Children under Five's Parenting Style in East Bogor Sub-district, Bogor City. Undergraduate script (unpublished). Department of Community Nutrition and Family Resources, Faculty of Agriculture, Bogor Agricultural University (IPB), Bogor.

Winarno FG. 1997. Food Chemistry and Nutrition. Gramedia Pustaka Utama Ltd., Jakarta.

1995. Nutrition and Food for baby and Post Breastfed baby. Pustaka Sinar Harapan, Jakarta. 